\title{
Relationship between clinical and pathological signs and severity of canine leishmaniasis
}

\author{
Relação entre sinais clínico-patológicos e gravidade da leishmaniose visceral canina \\ Raul Rio Ribeiro'*; Sydnei Magno da Silva²; Gustavo de Oliveira Fulgêncio³; \\ Marilene Suzan Marques Michalick'; Frédéric Jean Georges Frézard ${ }^{5}$
}

\begin{abstract}
${ }^{1}$ Centro de Ciências Agrárias, Ambientais e Biológicas, Universidade Federal do Recôncavo da Bahia - UFRB, Cruz das Almas, BA, Brasil
${ }^{2}$ Departamento de Imunologia, Microbiologia e Parasitologia, Instituto de Ciências Biomédicas, Universidade Federal de Uberlândia - UFU, Uberlândia, MG, Brasil

${ }^{3}$ Departamento de Clínica e Cirurgia Veterinárias, Escola de Veterinária, Universidade Federal de Minas Gerais - UFMG, Belo Horizonte, MG, Brasil

${ }^{4}$ Laboratório de Sorologia, Departamento de Parasitologia, Instituto de Ciências Biológicas, Universidade Federal de Minas Gerais - UFMG, Belo Horizonte, MG, Brasil

${ }^{5}$ Laboratório de Biofísica e Sistemas Nanoestruturados, Departamento de Fisiologia e Biofísica, Instituto de Ciências Biológicas, Universidade Federal de Minas Gerais - UFMG, Belo Horizonte, MG, Brasil
\end{abstract}

Received March 10, 2013

Accepted May 28, 2013

\begin{abstract}
Canine visceral leishmaniasis (CVL) is a zoonotic disease that presents variable clinical and laboratory aspects. The aims of this study were to identify the main biochemical/hematological status of dogs naturally infected with Leishmania (Leishmania) infantum and to associate theses parameters with clinical forms of CVL. Blood samples were analyzed from 51 dogs, 15 uninfected (control group) and 36 infected, which were classified clinically in three groups: asymptomatic $(n=12)$, oligosymptomatic $(n=12)$ and symptomatic $(n=12)$. All the infected dogs showed lower albumin/ globulin ratios (A-G ratio) than the limit of reference. The mean values of total protein, urea, $\alpha$-globulin 2 , globulin and A-G ratio of infected dogs were outside the reference interval and differed significantly from those of the controls. Anemia was detected only in groups that showed clinical signs of the disease, and a statistical analysis indicated a significantly higher frequency of lower eritrogram in these groups than in the asymptomatic group. In addition, a significant association was observed between anemia and the presence of the symptoms, with dogs displaying higher erythrogram values showing better clinical conditions. These results provide additional evidence that the clinical forms of CVL may reflect on the erythrogram status.
\end{abstract}

Keywords: Canine visceral leishmaniasis, clinical forms, laboratory findings, anaemia, relationship.

\section{Resumo}

A leishmaniose visceral canina (LVC) é uma zoonose com aspectos clínicos e laboratoriais variáveis. O objetivo deste trabalho foi identificar os principais achados hematológicos e bioquímicos em cáes naturalmente infectados com Leishmania (Leishmania) infantum e associar esses parâmetros com as formas clínicas da LVC. Foram analizadas amostras sanguíneas provenientes de 51 cães, sendo 15 cães náo infectados (grupo controle) e 36 infectados, os quais foram classificados clinicamente em três grupos: assintomáticos $(n=12)$, oligossintomáticos $(n=12)$ e sintomáticos $(n=12)$. Todos os cães infectados apresentaram valores na relação albumina/globulina (A/G) abaixo do limite inferior de referência. Os valores médios de proteína total, uréia, $\alpha-2$ globulina, globulina e A/G dos grupos de cáes infectados permaneceram fora dos intervalos de referências e significativamente diferente quando comparados aos do grupo controle. Anemia foi registrada somente nos grupos de animais que manifestavam sinais clínicos da enfermidade, sendo que nas análises estatísticas constatou-se frequencia significativamente maior de alteraçôes no eritrograma quando comparados ao grupo assintomático. Associação significativa foi observada entre anemia e a presença de sinais clínicos, onde os cáes com os maiores valores de eritrograma apresentavam a melhor condiçáo clínica. Os resultados fornecem evidência adicional que as formas clínicas da LVC podem refletir no eritrograma.

Palavras-chave: Leishmaniose visceral canina, formas clínicas, achados laboratoriais, anemia, relação.

\footnotetext{
*Corresponding author: Raul Rio Ribeiro

Centro de Ciências Agrárias, Ambientais e Biológicas, Universidade Federal do

Recôncavo da Bahia - UFRB, CEP 44380-000, Cruz das Almas, BA, Brazil

e-mail: raul@ufrb.edu.br
} 


\section{Introduction}

Leishmaniases, a group of diseases produced by the invasion of parasites of the genus Leishmania into the reticuloendothelial system of mammalian hosts, are transmitted primarily by sandflies of the genus Phlebotomus and Lutzomyia. These protozoans cause a wide variety of clinical forms ranging in severity from selfhealing cutaneous leishmaniasis (CL) to fatal disseminated visceral leishmaniasis (VL) (DUMONTEIL et al., 2003). In the Indian subcontinent and East Africa, kala-azar, or VL, is transmitted between people (i.e., anthroponotic). In the rest of the world, particularly in the highlands of China, Central Asia, the Middle East, Transcaucasia, the Mediterranean, and Central and South America, VL is a zoonosis; i.e., it is transmitted between animals and, secondarily, to people (COSTA, 2011). Today, zoonotic visceral leishmaniasis (ZVL) is one of the world's most important emerging diseases (WHO, 2010).

Since the discovery of canine visceral leishmaniasis (CVL), dogs have been considered reservoirs of Leishmania infantum (syn. L. chagasi), playing a key role in its transmission. During the course of the infection, the parasites spread and many organs are affected. Treatment of humans is essential to prevent death, although it does not provide satisfactory results in dogs (OLIVA et al., 2010).

The clinical diagnosis of CVL is complex, since much of the affected canine population does not exhibit clinical signs (MANCIANTI et al., 1988). Moreover, when dogs are ill, they manifest a variable and nonspecific clinical spectrum. In this context, routine biochemical and hematological tests have been proposed as additional diagnostic tools (GIAUFFRET et al., 1976), although the final diagnosis requires that the parasite be found in the tissues of dogs suspected of infection (SOLANO-GALLEGO et al., 2009).

A number of studies relating to CVL have focused on biochemical-hematological alterations in dogs naturally or experimentally infected with Leishmania (ABREU et al., 2011). The marked polyclonal humoral response that occurs after infection gives rise to visible changes in the electrophoretic plasma profile. In addition, high parasite loads in the components of mononuclear phagocyte system (MPS), e.g., in bone marrow and liver, triggering the occurrence of clinical pathology related to hepatic and hematopoietic functions (KEENAN et al., 1984b; AMUSATEGUI et al., 2003). Considering that parasite density in tissues increase according to the severity of clinical manifestations (GIUNCHETTI et al., 2006; REIS et al., 2006b), symptomatic dogs present significantly decreased levels of albumin and increased levels of globulin fraction, leading to an inversion of $\mathrm{A} / \mathrm{G}$ ratio when compared to asymptomatic dogs, suggesting a relationship between the presence of exacerbated clinical forms of CVL, serum protein levels and humoral immune response alterations (GIUNCHETTI et al., 2006, 2008; REIS et al., 2006b). Biochemical findings in CVL include alterations in the hepatic enzymes aspartate aminotransferase, alanine aminotransferase and alkaline phosphatase (SLAPPENDEL, 1988; ABRANCHES et al., 1991).

Anemia is a frequent clinical finding in dogs naturally or experimentally infected with Leishmania (CIARAMELLA et al.,
1997; KOUTINAS et al., 1999; COSTA-VAL et al., 2007). A recent evaluation of the correlation between the hematological status, the stage of the disease, and infectivity showed that dogs with low hematocrit values infected more female sandflies than those presenting normal values (COSTA-VAL et al., 2007). On the other hand, the existence of a correlation between anemia and the severity of the disease is still controversial. Although a correlation between anemia and clinical signs has been reported previously (AMUSATEGUI et al., 2003; REIS et al., 2006b), this was not confirmed in the study of Costa-Val et al. (2007). This knowledge is important to understand the pathogenesis of CVL, as well as to evaluate the potential use of these clinical and pathological parameters to aid diagnostics and therapeutic monitoring. In this context, the purpose of this study was to identify laboratory findings and their relationship with clinical forms in dogs carrying the visceral leishmaniasis.

\section{Materials and Methods}

\section{Study dogs}

Thirty-six mongrel dogs (weighing 8-15 kg) naturally infected with Leishmania infantum and exhibiting different clinical forms of canine leishmaniasis were identified and captured during an epidemiological survey carried out by the Municipal Zoonosis Control Center of Santa Luzia (state of Minas Gerais in southeast Brazil). The serological diagnosis was performed at the Serology Laboratory of the Institute of Biological Sciences, Federal University of Minas Gerais (UFMG), by indirect immunofluorescence assay (IFAT) and enzyme-linked immunosorbent assay (ELISA). All the dogs tested positive by IFAT ( $\geq 1: 40$ dilutions) and ELISA (optical density $>0.100 ; \geq 1: 400$ dilutions). In addition, a parasitological diagnosis was performed by observation of parasite forms in cytological examinations and/or cultures of bone marrow aspirates in Novy-Nicolle-McNeal (NNN) medium enriched with minimum essential medium ( $\alpha$-MEM). In addition, 15 healthy dogs with negative serological and parasitological diagnosis for L. infantum also participated in this study as the uninfected control group.

Prior to the assays, the dogs were maintained in quarantine in kennels, during 30 days, and were treated for intestinal helminth infections (Canex Composto ${ }^{\oplus}$, Vetbrands Health Animal) and ectoparasite infestations (Front Line ${ }^{\varpi}$, Merial), and were immunized against viral infections (Defensor ${ }^{\oplus}$ and Vanguard $^{\odot}$ HTLP 5/CV-L, vaccine Pfizer, Brazil). Throughout the experimental period, the dogs were housed in a screened kennel to prevent reinfection and received drinking water and balanced dog food ad libitum (Pedigree Champ ${ }^{\oplus}$ Effem). The present research adhered to the Principles of Laboratory Animal Care (NIH publication \#85-23, revised in 1985) and was approved by the Animal Ethics Committee (CETEA) of the Federal University of Minas Gerais - UFMG (Brazil) under Protocol No. 123/05.

\section{Groups}

The infected dogs were classified and grouped according to their external clinical signs (MANCIANTI et al., 1988), as 
follows: asymptomatic dogs $(n=12)$ - absence of clinical signs; oligosymptomatic dogs $(n=12)$ - lymphadenopathy, small weight loss and/or dull fur; symptomatic dogs $(n=12)$ - all or some of the characteristic signs of the disease, e.g., skin disorders (alopecia, skin ulcers and hyperkeratosis), onychogryphosis, severe weight loss, and opthalmopathies.

\section{Laboratory evaluations}

After the quarantine period, blood samples were drawn once from the cephalic vein of all the dogs for biochemical and hematological evaluation. The analyses, which were performed by a commercial veterinary laboratory (Tecsa Laboratories), involved complete hemogram (red blood cells, packed cell volume, hemoglobin, white blood cells, neutrophils, lymphocytes, monocytes, eosinophils, and platelets), renal profile (urea and creatinine), hepatic profile (alanine aminotransferase (ALT), aspartate aminotransferase (AST), alkaline phosphatase and bilirubins) and serum protein electrophoretogram (total serum proteins, albumin, globulin, albumin-globulin ratio (A-G ratio), $\alpha$-globulin 1, $\alpha$-globulin 2; $\beta$-globulin and $\gamma$-globulin).

\section{Statistical analysis}

According to the Kolmogorov-Smirnov test, experimental data were distributed normally. Comparisons were then made of laboratory results between groups, using analysis of variance (ANOVA). Possible associations between laboratory findings and different CVL groups (asymptomatic, oligosymptomatic and symptomatic) were analyzed through Fischer's Exact Test. The analysis of correlations between variables (i.e., between clinical conditions and laboratory parameters) was performed by the Spearman correlation method. All the statistical analyses were performed using Prism 4.0 and Minitab 14 software (95\% significance level).

\section{Results}

The average values of hematological (Table 1) and biochemical (Table 2) parameters in dogs with different clinical forms of visceral leishmaniasis were determined. Despite the evidence of anemia in oligosymptomatic and symptomatic dogs, characterized by reduced hematocrit (reference interval 37.00-55.00\%) and/or hemoglobin levels (reference interval 12.00-18.00 g/dL), the comparison of mean values of hemogram parameters among the different groups revealed no significant differences (one-way ANOVA, $p>0.05$ ). However, statistical analyses indicated a significantly lower frequency of hematological disorders consistent with anemia (reduced erythrocyte count, hemoglobin or hematocrit levels) in the asymptomatic group than in groups with clinical signs of CVL $(p<0.05$, Fischer's Exact Test) (Figure 1). In addition, a significant correlation was found between the clinical category and anemia ( $p<0.05$, Spearman), and dogs exhibiting the best clinical condition showed the highest erythrogram values.

The biochemical evaluation revealed that, regardless of the clinical condition, most of the laboratory results, i.e., mean values of urea, total protein, $\alpha$-globulin 2 , globulin and A-G ratio of leishmaniasis groups, were outside the physiological limits and differed significantly (one-way ANOVA, $p>0.05$ ) from those of healthy dogs (Figure 2).

\section{Discussion}

Although the literature contains many reports of clinical and laboratory findings on CVL, the approach employed often favors the individual analysis of parameters (SLAPPENDEL, 1988;

Table 1. Hematological parameters of dogs naturally infected with different clinical forms of visceral leishmaniasis and uninfected.

\begin{tabular}{|c|c|c|c|c|c|c|}
\hline \multirow{2}{*}{$\begin{array}{l}\text { Quantitative } \\
\text { Parameters }\end{array}$} & \multirow[b]{2}{*}{$\begin{array}{l}\text { Reference } \\
\text { Interval }^{*}\end{array}$} & \multicolumn{5}{|c|}{ Clinical Forms } \\
\hline & & $\begin{array}{c}\text { Asymptomatic } \\
(n=12)\end{array}$ & $\begin{array}{c}\text { Oligosymptomatic } \\
(n=12)\end{array}$ & $\begin{array}{c}\text { Symptomatic } \\
(n=12)\end{array}$ & $\begin{array}{c}\text { Infected } \\
(n=36)\end{array}$ & $\begin{array}{c}\text { Uninfected } \\
(n=15)\end{array}$ \\
\hline $\begin{array}{l}\text { Red Blood Cells } \\
\left(\mathrm{mill} / \mathrm{mm}^{3}\right)\end{array}$ & $5.50-8.50$ & $6.71 \pm 1.50$ & $5.51 \pm 1.29$ & $5.64 \pm 0.89$ & $5.95 \pm 1.33$ & $6.70 \pm 0.62$ \\
\hline Hemoglobin (g/dl) & $12.00-18.00$ & $14.26 \pm 3.13$ & $11.68 \pm 2.88$ & $12.42 \pm 2.05$ & $12.78 \pm 2.87$ & $13.71 \pm 1.02$ \\
\hline Hematocrit (\%) & $37.00-55.00$ & $41.53 \pm 9.52$ & $34.58 \pm 8.18$ & $36.74 \pm 5.94$ & $37.68 \pm 8.32$ & $42.81 \pm 2.53$ \\
\hline $\begin{array}{l}\text { White Blood Cells } \\
\left(\text { Cells } / \mathrm{mm}^{3}\right)\end{array}$ & $5500-16500$ & $16924.17 \pm 6548.35$ & $14032.50 \pm 4325.38$ & $14450.83 \pm 7506.86$ & $15135.83 \pm 6224.35$ & $7702.85 \pm 3247.50$ \\
\hline $\begin{array}{l}\text { Neutrophils } \\
\left(\text { Cells/mm } / \mathrm{mm}^{3}\right)\end{array}$ & $3300-12705$ & $10993 \pm 4967.10$ & $10182.42 \pm 3348.29$ & $9813.81 \pm 5496.56$ & $10329.75 \pm 4585.01$ & $4880.57 \pm 2409.78$ \\
\hline $\begin{array}{l}\text { Lymphocytes } \\
\left(\text { Cells } / \mathrm{mm}^{3}\right)\end{array}$ & $660-4950$ & $4586.68 \pm 1984.35$ & $3473.98 \pm 1337.00$ & $3438.83 \pm 1830.24$ & $3833.16 \pm 1773.23$ & $2277.71 \pm 889.61$ \\
\hline $\begin{array}{l}\text { Monocytes } \\
\left(\text { Cells } / \mathrm{mm}^{3}\right)\end{array}$ & $0-1650$ & $248.58 \pm 145.30$ & $258.35 \pm 103.09$ & $262.84 \pm 145.79$ & $256.59 \pm 129.20$ & $260.14 \pm 111.30$ \\
\hline $\begin{array}{l}\text { Eosinophils } \\
\left(\text { Cells } / \mathrm{mm}^{3}\right)\end{array}$ & $0-1650$ & $942.14 \pm 628.63$ & $712.80 \pm 504.62$ & $852.39 \pm 764.90$ & $835.78 \pm 630.29$ & $262.28 \pm 227.10$ \\
\hline Platelets $\left(\mathrm{mill} / \mathrm{mm}^{3}\right)$ & $200-500$ & $243.17 \pm 124.66$ & $183.00 \pm 93.68$ & $240.33 \pm 119.36$ & $222.17 \pm 113.62$ & $461.57 \pm 164.40$ \\
\hline
\end{tabular}

Data are given as means \pm standard deviation. Values represented in bold are above or below the physiological range adopted for the canine species.

${ }^{*}$ Recommended by the laboratory that analyzed the samples (Tecsa Laboratories). 
Table 2. Biochemical parameters of dogs naturally infected with different clinical forms of visceral leishmaniasis and uninfected.

\begin{tabular}{|c|c|c|c|c|c|c|}
\hline \multirow{2}{*}{$\begin{array}{l}\text { Quantitative } \\
\text { Parameters }\end{array}$} & \multirow{2}{*}{$\begin{array}{l}\text { Reference } \\
\text { Interval* }\end{array}$} & \multicolumn{5}{|c|}{ Clinical Forms } \\
\hline & & $\begin{array}{c}\text { Asymptomatic } \\
(n=12)\end{array}$ & $\begin{array}{l}\text { Oligosymptom- } \\
\text { atic }(n=12)\end{array}$ & $\begin{array}{c}\text { Symptomatic } \\
(n=12)\end{array}$ & $\begin{array}{c}\text { Infected } \\
(n=36)\end{array}$ & $\begin{array}{c}\text { Uninfected } \\
(n=15)\end{array}$ \\
\hline Urea $(\mathrm{mg} / \mathrm{dl})$ & $15-40$ & $44.65 \pm 9.05$ & $51.07 \pm 26.17$ & $43.33 \pm 11.31$ & $46.35 \pm 17.12$ & $20.70 \pm 4.75$ \\
\hline Creatinine $(\mathrm{mg} / \mathrm{dl})$ & $0.50-1.50$ & $0.92 \pm 0.21$ & $0.88 \pm 0.27$ & $1.00 \pm 0.45$ & $0.94 \pm 0.32$ & $0.50 \pm 0.11$ \\
\hline ALT (U.I./l) & $10-88$ & $47.33 \pm 17.21$ & $36.83 \pm 28.74$ & $40.33 \pm 10.50$ & $41.50 \pm 16.05$ & $77.75 \pm 34.93$ \\
\hline AST (U.I./l) & $10-88$ & $45.83 \pm 12.27$ & $42.00 \pm 13.44$ & $56.67 \pm 31.47$ & $48.17 \pm 21.33$ & $43.75 \pm 16.62$ \\
\hline FA (U.I./l) & $10-96$ & $39.00 \pm 17.73$ & $30.83 \pm 8.72$ & $33.00 \pm 10.61$ & $34.28 \pm 13.05$ & $87.5 \pm 28.99$ \\
\hline Total Bilirubins (mg/dl) & $0.10-0.60$ & $0.42 \pm 0.07$ & $0.39 \pm 0.03$ & $0.41 \pm 0.07$ & $0.41 \pm 0.06$ & $0.23 \pm 0.07$ \\
\hline Total Protein $(\mathrm{g} / \mathrm{dl})$ & $5.40-7.70$ & $8.53 \pm 1.34$ & $8.19 \pm 0.70$ & $8.34 \pm 0.81$ & $8.35 \pm 0.97$ & $6.80 \pm 0.49$ \\
\hline Albumin $(\mathrm{g} / \mathrm{dl})$ & $2.30-3.80$ & $2.69 \pm 0.36$ & $2.30 \pm 0.81$ & $2.57 \pm 0.52$ & $2.52 \pm 0.60$ & $3.46 \pm 0.31$ \\
\hline Globulin (g/dl) & $2.30-5.20$ & $5.67 \pm 1.58$ & $5.50 \pm 0.93$ & $5.85 \pm 0.83$ & $5.67 \pm 1.13$ & $3.34 \pm 0.38$ \\
\hline$\alpha$-globulin $1(\mathrm{~g} / \mathrm{dl})$ & $0.20-0.50$ & $0.26 \pm 0.03$ & $0.25 \pm 0.05$ & $0.21 \pm 0.05$ & $0.24 \pm 0.05$ & $0.25 \pm 0.02$ \\
\hline$\alpha$-globulin $2(\mathrm{~g} / \mathrm{dl})$ & $0.30-1.10$ & $1.44 \pm 0.20$ & $1.36 \pm 0.31$ & $1.30 \pm 0.24$ & $1.37 \pm 0.26$ & $0.65 \pm 0.19$ \\
\hline$\beta$-globulin (g/dl) & $1.20-2.70$ & $2.11 \pm 0.55$ & $2.16 \pm 0.98$ & $2.43 \pm 0.50$ & $2.23 \pm 0.70$ & $2.02 \pm 0.35$ \\
\hline$\gamma$-globulin $(\mathrm{g} / \mathrm{dl})$ & $0.80-2.20$ & $1.91 \pm 1.28$ & $2.03 \pm 1.05$ & $1.92 \pm 0.90$ & $1.95 \pm 1.06$ & $1.62 \pm 0.86$ \\
\hline A-G Ratio & $0.80-1.00$ & $0.50 \pm 0.17$ & $0.43 \pm 0.15$ & $0.48 \pm 0.16$ & $0.47 \pm 0.17$ & $1.00 \pm 0.12$ \\
\hline
\end{tabular}

Data are given as means \pm standard deviation. Values represented in bold are above or below the physiological range adopted for the canine species. ${ }^{*}$ Recommended by the laboratory that analyzed the samples (Tecsa Laboratories).

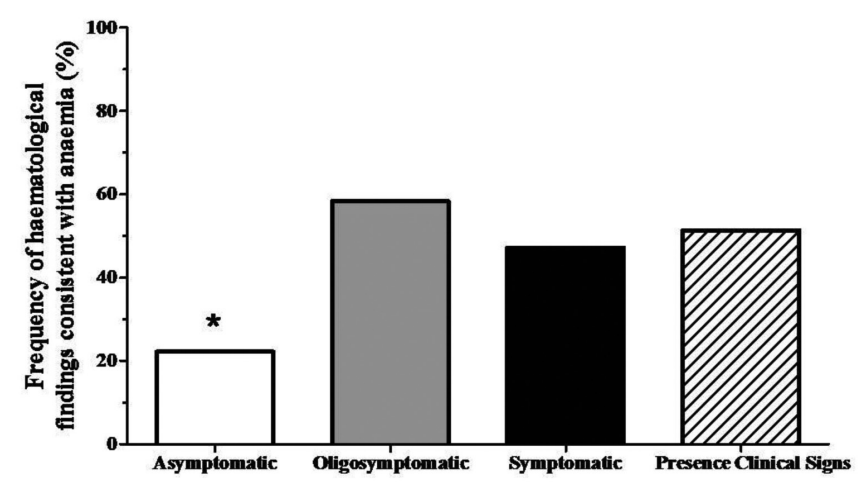

Figure 1. Frequency of hematological disorders consistent with anemia (reduced erythrocyte count, hemoglobin or hematocrit levels) in the erythrograms of dogs naturally infected with different clinical forms of visceral leishmaniasis. Asymptomatic Group, $n=12$; Oligosymptomatic Group, $n=12$; Symptomatic Group, $n=12$; Presence of Clinical Signs (Oligosymptomatic and Symptomatic Groups Together), $n=24$. ${ }^{*} p<0.05$ (Fischer's Exact Test for comparison of groups).

FERRER, 1992; CIARAMELLA et al., 1997). Indeed, very few studies have reported clinical and laboratory evaluations of well characterized research groups of dogs with CVL, allowing for the identification of correlations between different variables related to this disease (AMUSATEGUI et al., 2003; REIS et al., 2006b; COSTA-VAL et al., 2007). In this study, the clinical classification was chosen because of its widespread adoption in the literature of both the Old and New World, whether in natural or experimental infection (PINELLI et al., 1994, 1995; TRAVI et al., 2001; FERNÁNDEZ-PÉREZ et al., 2003; COSTA-VAL, 2004; REIS et al., 2006a, b).

The analysis revealed dysproteinemia, azotemia and anemia as the main laboratory findings in dogs naturally infected with different clinical forms of visceral leishmaniasis. According to the literature, anemia is considered a common finding in CVL (KEENAN et al., 1984a; FERRER 1992). It is likely that more than one factor is involved in the etiology of anemia, such as hemorrhage, hemolysis, chronic renal failure, bone marrow hypoplasia or aplasia, and decreased lipid fluidity of the erythrocyte membrane (SLAPPENDEL; GREENE, 1990; BURILLO et al., 1994; KOUTINAS et al., 1999; DE LUNA et al., 2000). Although the pathogenesis of anemia in CVL is multifactorial, the fact that 50 to $70 \%$ of patients present normocytic/normochromic and non-regenerative anemia (CIARAMELLA et al., 1997; KOUTINAS et al., 1999; REIS et al., 2006b) suggests, at the very least, that erythropoiesis is often compromised due to infectioninduced changes in bone marrow (GIAUFFRET et al., 1976) and/or kidneys (KOUTINAS et al., 1999). In the present survey, the individual analysis of all the dogs indicated that anemia was normocytic/normochromic and non-regenerative. Although no urinalysis was performed, one can reasonably assume that most of the dogs had only incipient nephropathy, since the kidneys were still able to maintain creatinine at physiological levels (Table 2). Thus, the pathogenesis of anemia verified in this work seems to be related to the hematopoietic functions of the bone marrow. On the other hand, the significant increase in alpha- 2 globulins (Table 2) also suggests the possibility of anemia of chronic disease (anemia inflammatory response), since these proteins are considered acute phase proteins.

According to the present work, the presence of external clinical signs in dogs with visceral leishmaniasis was associated with a higher number of hematological disorders consistent with anemia and lower erythrogram values. Altogether, these data suggest that the clinical form of CVL may reflect the animal's erythrogram status. This relationship can be explained by the fact that the parasite load in the bone marrow of the dogs is related with its clinical signs (REIS et al., 2006a). Based on this principle, the higher 

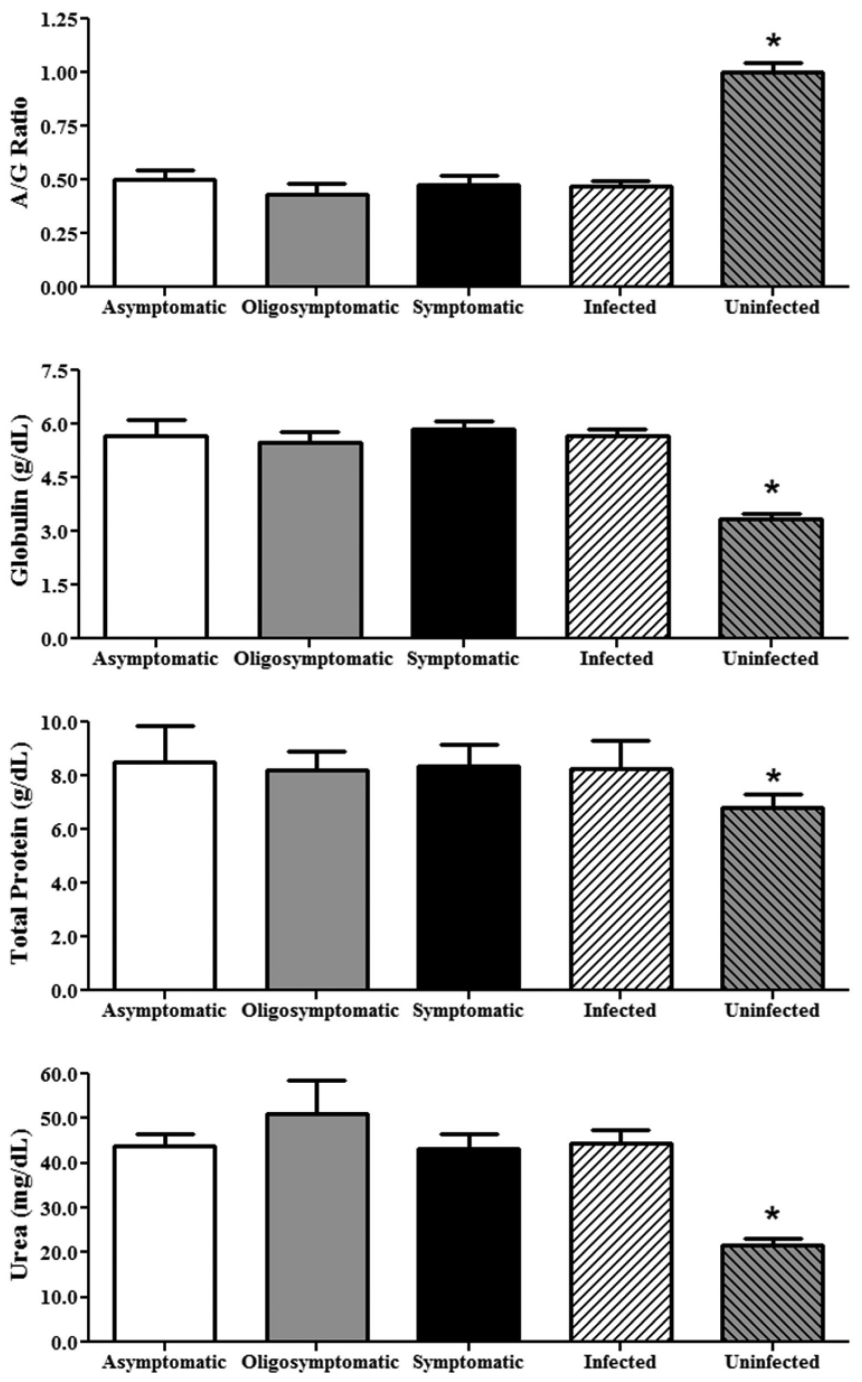

Figure 2. Evaluation of biochemical parameters of dogs naturally infected with different clinical forms of visceral leishmaniasis and of uninfected dogs. The results are shown as average values \pm standard error of measurement. Asymptomatic Group, $n=12$; Oligosymptomatic Group, $n=12$; Symptomatic Group, $n=12$; Infected Group (Asymptomatic, Oligosymptomatic and Symptomatic Groups Together), n=36; Uninfected Group, $n=15$. ${ }^{*} p<0.05$ (one-way ANOVA, followed by Tukey's Multiple Comparison Post-Hoc Test, for comparison of groups).

the parasite load (sick dogs) the worse the medullary disorders (anemia and lower erythrogram values). According to Abreu et al. (2011), the bone marrow is a major hematopoietic organ and an important storage site of parasites in Leishmania-infected dogs, which facilitates the occurrence of dysfunctions in the production of erythrocytes, leukocytes and platelets. Two earlier studies also found a relationship between anemia and clinical forms (AMUSATEGUI et al., 2003; REIS et al., 2006b).

Apparently, the bone marrow dysfunction did not involve precursor cells of leukocytes, since all the leukogram values lay within the physiological range (except for total leukocytes in the asymptomatic group), which confirms the findings of other authors who considered infrequent changes in white blood cells in CVL (AMUSATEGUI et al., 2003; COSTA-VAL et al., 2007).

Azotemia is not surprising in CVL, since it is recognized that kidney damage associated with the disease is almost inevitable (FERRER, 1992; DIAZ-ESPINEIRA; SLAPPENDEL, 1997). Although CVL is often characterized by hypergammaglobulinemia (polyclonal $\mathrm{B}$ cell response) and hypoalbuminemia (renal and/or liver failure), the electrophoresis evaluation in this work did not show significant changes in albumin and $\gamma$-globulin values. Furthermore, no correlation was observed between the clinical category and the different proteinogram parameters. These data contradict the previous findings of most authors (SANCHIS et al., 1976; CIARAMELLA et al., 1997; KOUTINAS et al., 1999; AMUSATEGUI et al., 2003). The disparity of these results can be attributed to the fact that dysproteinemia, albeit more evident as the disease progresses, may in many cases precede the appearance of clinical signs (GROULADE, 1988; BOURDOISEAU et al., 1997), interfering with the expected correlation.

During the individual analysis, all the dogs with visceral leishmaniasis that participated in this assay showed values of A-G ratio below the lower limit of reference, a detail that reconfirms this parameter as the most reliable one (VALLADARES et al., 1988; COSTA-VAL, 2004) and reinforces its importance as a biochemical marker for diagnosis and therapeutic monitoring.

\section{Acknowledgements}

The authors acknowledge the financial support of the Brazilian research funding agency CAPES (Federal Agency for the Support and Improvement of Higher Education).

\section{References}

Abranches P, Santos-Gomes G, Rachamim N, Campino L, Schnur LF, Jaffe CL. An experimental model for canine visceral leishmaniasis. Parasite Immunol 1991; 13(5): 537-550. PMid:1956700. http://dx.doi. org/10.1111/j.1365-3024.1991.tb00550.x

Abreu RT, Carvalho MG, Carneiro CM, Giunchetti RC, TeixeiraCarvalho A, Martins-Filho OA, et al. Influence of clinical status and parasite load in the erythropoiesis and leucopoiesis in dogs naturally infected by Leishmania (Leishmania) chagasi. PLOS ONE 2011; 6(5): e18873. PMid:21572995 PMCid:PMC3091854. http://dx.doi. org/10.1371/journal.pone.0018873

Amusategui I, Sainz A, Rodríguez F, Tesouro MA. Distribution and relationships between clinical and biopathological parameters in canine leishmaniasis. Eur J Epidemiol 2003; 18(2): 147-156. PMid:12733837. http://dx.doi.org/10.1023/A:1023090929302

Bourdoiseau G, Bonnefont C, Hoaerau E, Boehringer C, Stolle T, Chabanne L. Specific IgG1 and IgG2 antibody and lymphocyte subset levels in naturally Leishmania infantum-infected treated and untreated dogs. Vet Immunol Immunopathol 1997; 59(1-2): 21-30. http://dx.doi. org/10.1016/S0165-2427(97)00072-X

Burillo FL, Pérez FMG, Lieza P, Fabián MCA. Iron status and anemia in canine leishmaniasis. Rev Med Vet 1994; 145(3): 171-176. 
Ciaramella P, Oliva G, De Luna R, Gradoni L, Ambrosio R, Cortese $\mathrm{L}$, et al. A retrospective clinical study of canine leishmaniasis in 150 dogs naturally infected by Leishmania infantum. Vet Rec 1997; 141(21): 539543. PMid:9413121. http://dx.doi.org/10.1136/vr.141.21.539

Costa CHN. How effective is dog culling in controlling zoonotic visceral leishmaniasis? A critical evaluation of the science, politics and ethics behind this public health policy. Rev Soc Bras Med Trop 2011; 44(2): 232-242. PMid:21468480. http://dx.doi.org/10.1590/ S0037-86822011005000014

Costa-Val AP. Tratamento da leishmaniose visceral canina com antimonial pentavalente encapsulado em lipossomas [Tese]. Belo Horizonte: Universidade Federal de Minas Gerais; 2004. PMid:15309237.

Costa-Val AP, Cavalcanti RR, Gontijo NF, Mickalick MSM, Alexander B, Williams P, et al. Canine visceral leishmaniasis: relationships between clinical status, humoral imune response, haematology and Lutzomyia (Lutzomyia) longipalpis infectivity. Vet J 2007; 174(3): 637-643.

De Luna R, Ferrante M, Severino L, Ambrosio R, Piantedosi D, Gradoni $\mathrm{L}$, et al. Decreased lipid fluidity of the erythrocyte membrane in dogs with leishmaniasis-associated anaemia. J Comp Pathol 2000; 122(2-3): $213-$ 216. PMid:10684691. http://dx.doi.org/10.1053/jcpa.1999.0357

Diaz-Espineira MM, Slappendel RJ. A case of autochthonous canine leishmaniasis in the Netherlands. Vet Q 1997; 19(2): 69-71. PMid:9225436. http://dx.doi.org/10.1080/01652176.1997.9694744

Dumonteil E, Jesus MRS, Javier EO, Del Rosario MGM. DNA vaccines induce partial protection against Leishmania mexicana. Vaccine 2003; 21(17-18): 2161-2168. http://dx.doi.org/10.1016/S0264410X(02)00769-7

Fernández-Pérez FJ, Gómez-Muñoz MAT, Méndez S, Alunda JM. Leishmania-specific lymphoproliferative responses and IgG1/ IgG2 immunodetection patterns by Western blot in asymptomatic, symptomatic and treated dogs. Acta Trop 2003; 86(1): 83-91. http:// dx.doi.org/10.1016/S0001-706X(03)00004-4

Ferrer L. Leishmaniasis. In: Kirk RW, Bonagura JD. Current veterinary therapy. Philadelphia: Saunders; 1992. p. 266-270.

Giauffret A, Sanchis R, Vitu C. Les examens de laboratoire dans la Leishmaniose canine, I. Application au diagnostic, au pronostic et au contrôle du traitement dans la maladie naturelle. Rev Med Vet 1976; 127(6): 913-930.

Giunchetti RC, Mayrink W, Genaro O, Carneiro CM, Corrêa-Oliveira R, Martins-Filho OA, et al. Relationship between Canine Visceral Leishmaniosis and the Leishmania (Leishmania) chagasi Burden in Dermal Inflammatory Foci. J Comp Pathol 2006; 135(2-3): 100-107. PMid:16959259. http://dx.doi.org/10.1016/j.jcpa.2006.06.005

Giunchetti RC, Mayrink W, Carneiro CM, Corrêa-Oliveira R, Martins-Filho OA, Marques MJ, et al. Histopathological and immunohistochemical investigations of the hepatic compartment associated with parasitism and serum biochemical changes in canine visceral leishmaniasis. Res Vet Sci 2008; 84(2): 269-277. PMid:17604064. http://dx.doi.org/10.1016/j.rvsc.2007.04.020

Groulade PL. L'intérêt de l'electrophorése des protéins sériques dans le bilan et le suivi au cours de la leishmaniose canine. Prat Med Chir Animal Comp 1988; 23(1): 93-101.

Keenan CM, Hendricks LD, Lightner L, Johnson AJ. Visceral Leishmaniasis in the German Shepherd dog. II. Pathology. Vet Pathol 1984a; 21(1): 80-86. PMid:6710817.

Keenan CM, Hendricks LD, Lightner L, Webster HK, Johnson AJ. Visceral Leishmaniasis in the German Shepherd dog. I. Infection, clinical disease, and clinical pathology. Vet Pathol 1984b; 21(1): 74-79. PMid:6710816.

Koutinas AF, Polizopoulou ZS, Saridomichelakis MN, Argyriadis D, Fytianou A, Plevraki KG. Clinical considerations on canine visceral leishmaniasis in Greece: a retrospective study of 158 cases (1989-1996). J Am Anim Hosp Assoc 1999; 35(5): 376-383. PMid:10493412.

Mancianti F, Gramiccia M, Gradoni L, Pieri S. Studies on canine leishmaniais control. 1. Evolution of infection of different clinical forms of canine leishmaniasis following antimonial treatment. Trans $R$ Soc Trop Med Hyg 1988; 82(4): 566-567. http://dx.doi.org/10.1016/00359203(88)90510-X

Oliva G, Roura X, Crotti A, Maroli M, Castagnaro M, Gradoni $\mathrm{L}$, et al. Guidelines for treatment of leishmaniasis in dogs. J Am Vet Med Assoc 2010; 236(11): 1192-1198. PMid:20513197. http://dx.doi. org/10.2460/javma.236.11.1192

Pinelli E, Killick-Kendrick R, Wagenaar J, Bernadina W, Real G, Ruitenberg J. Cellular and humoral immune responses in dogs experimentally and naturally infected with Leishmania infantum. Infect Immun 1994; 62(1): 229-235. PMid:8262632 PMCid:PMC186091.

Pinelli E, Gonzalo RM, Boog CJP, Rutten VPMG, Gebhard D, Real G, et al. Leishmania infantum-specific $\mathrm{T}$ cell lines derived from asymptomatic dogs that lyse infected macrophages in a major histocompatibility complex-restricted manner. Eur J Immunol 1995; 25(6): 1594-1600. PMid:7614987. http://dx.doi.org/10.1002/eji.1830250619

Reis AB, Teixeira-Carvalho A, Giunchetti RC, Guerra LL, Carvalho MG, Mayrink W, et al. Phenotypic features of circulating leucocytes as immunological markers for clinical status and bone marrow parasite density in dogs naturally infected by Leishmania chagasi. Clin Exp Immunol 2006a; 146(2): 303-311. PMid:17034583 PMCid:PMC1942052. http://dx.doi.org/10.1111/j.13652249.2006.03206.x

Reis AB, Martins-Filho OA, Teixeira-Carvalho A, Carvalho MG, Mayrink W, França-Silva JC, et al. Parasite density and impaired biochemical/ hematological status are associated with severe clinical aspects of canine visceral leishmaniasis. Res Vet Sci 2006b; 81(1): 68-75. PMid:16288789. http://dx.doi.org/10.1016/j.rvsc.2005.09.011

Sanchis R, Vitu C, Giauffret A. Les examens de laboratoire dans la leishmaniose canine. Rev Med Vet 1976; 127(1): 1191-1202.

Slappendel RJ. Canine leishmaniasis: a review based on 95 cases in the Netherlands. Vet Q 1988; 10(1): 1-16. PMid:3287754. http://dx.doi. org/10.1080/01652176.1988.9694140

Slappendel RJ, Greene CE. Leishmaniasis. In: Mills LE. Infectious diseases of the dog and cat. Philadelphia: Saunders; 1990. p. 769-777.

Solano-Gallego L, Koutinas A, Miró G, Cardoso L, Pennisi MG, Ferrer $\mathrm{L}$, et al. Directions for the diagnosis, clinical staging, treatment and prevention of canine leishmaniosis. Vet Parasitol 2009; 165(1-2):1-18 PMid:19559536. http://dx.doi.org/10.1016/j.vetpar.2009.05.022

Travi BL, Tabares CJ, Cadena H, Ferro C, Osorio Y. Canine visceral leishmaniasis in Colombia: relationship between clinical and parasitologic status and infectivity for sand flies. Am J Trop Med Hyg 2001; 64(3-4): 119-124. PMid:11442205.

Valladares JE, Riera C, Alberola J, Gállego M, Portús M, Cristòfol $\mathrm{C}$, et al. Pharmacokinetics of meglumine antimoniate after administration of a multiple dose in dogs experimentally infected with Leishmania infantum. Vet Parasitol 1998; 75(1): 33-40. http://dx.doi.org/10.1016/ S0304-4017(97)00193-3

World Health Organization - WHO. Control of the leishmaniases. Tech Rep Ser 2010; 949: 1-186. 